\title{
Metástasis mandibular de adenocarcinoma gástrico. Presentación de un caso
}

\section{Mandibular metastases of gastric adenocarcinoma. A case report}

\author{
J. Ferreras Granado ${ }^{1}$, Á. García-Rozado González , G. Gómez Oliveira², I. Vázquez Mahía', \\ J.L. López-Cedrún Cembranos ${ }^{3}$
}

\begin{abstract}
Resumen: Los tumores malignos de la cavidad oral y mandíbula representan aproximadamente un $5 \%$ de todas las neoplasias malignas del cuerpo, y sólo entre el 1 y el $4 \%$ son consideradas como metástasis. Tienen su localización más frecuente a nivel de la mandíbula (80\%), fundamentalmente en la región molar. Las metástasis mandibulares, cuando aparecen, suelen tener su origen en tumores primarios que asientan en la mama, pulmón, riñón, tiroides, intestinos y próstata; y con menor frecuencia en el estómago, testículos y vesícula biliar.

Suelen afectar a pacientes de edad avanzada ( $4^{\mathrm{a}}-7^{\mathrm{a}}$ décadas de la vida) $\sin$ predilección por el sexo.

El tratamiento en general es paliativo y pasa por el uso de la radioterapia, quimioterapia y hormonoterapia, reservando la cirugía para casos aislados. Describimos un caso de metástasis mandibular en un paciente adulto como primera manifestación clínica de un adenocarcinoma gástrico.
\end{abstract}

Palabras clave: Metástasis mandibular; Adenocarcinoma gástrico.

Recibido: 06.02 .06

Aceptado: 18.12 .06

\begin{abstract}
Malignant tumors of the mouth and jaws represents approximately 5\% of all malignant neoplasms in the body, and only 1-4\% are considered to be metastatic. They are most frequently located in the mandible (80\%), fundamentally in the molar region. Metastases to the jaws are usually from breast, lung, kidney, thyroid gland, intestines, and prostate gland; and less frequently from stomach, testes, and bladder.

They are more frequent in elderly patients (between 4th and $7^{\text {th }}$ decades) with no gender differences.

Treatment is usually palliative and based on the use of radiotherapy, chemotherapy and hormonal therapy. Surgery is only used in selected cases.

A case of mandibular metastases as first sign of malignant disease of gastric adenocarcinoma is reported.
\end{abstract}

Key words: Mandibular metastases; Gastric adenocarcinoma.

\footnotetext{
1 Médico Adjunto.

2 Médico Residente.

3 Jefe de Servicio.

Servicio de Cirugía Oral y Maxilofacial

CHU Juan Canalejo. La Coruña, España
}

\section{Correspondencia:}

Dr. José Ferreras Granado

$\mathrm{CHU}$ Juan Canalejo

Servicio de Cirugía Oral y Maxilofacial

As Xubias de Arriba, 84

15006 La Coruña, España

Email: joseferreras@terra.es 


\section{Introduccción}

Los tumores malignos de la cavidad oral y mandíbula representan aproximadamente un 5\% de todas las neoplasias malignas del cuerpo, y sólo entre el 1 y el $4 \%$ son consideradas como metástasis..$^{1,2}$ Tienen su localización más frecuente a nivel de la mandíbula (80\%), fundamentalmente en la región molar. ${ }^{3,4}$ El origen más frecuente es en tumores primarios que asientan en la mama, pulmón, riñón, tiroides, intestinos y próstata, y con menor frecuencia en el estómago, testículos y vesícula biliar. ${ }^{5-7}$

Suelen afectar a personas de edad avanzada ( $4^{\mathrm{a}}-7^{\mathrm{a}}$ décadas de la vida) $\sin$ diferencias en cuanto al sexo, 1,6,7 aunque hay autores que defienden una mayor incidencia en mujeres con respecto a los varones. 4,5

La presentación clínica más frecuente es una masa dolorosa de crecimiento relativamente rápido en la región molar mandibular. 1,4,5,7 Otras manifestaciones menos frecuentes incluyen las parestesias del labio inferior, la movilidad o incluso la pérdida de piezas dentarias, así como la presencia de sangrado intraoral. ${ }^{8-10}$ Está descrita, aunque de forma excepcional, la afectación bilateral ó multicéntrica de la mandíbula. ${ }^{11}$

El diagnóstico radiológico es complicado ya que no existe una imagen patognomónica y, en ocasiones, los hallazgos radiológicos son inexistentes. Cuando aparecen, suelen manifestarse como una imagen radiolúcida de márgenes mal definidos, aunque a veces, como en el caso de la metástasis de mama ó de próstata, la imagen puede ser radiopaca. 9,10

El diagnóstico diferencial incluye diversas entidades de aspecto radiológico similar como osteomielitis, abscesos y quistes óseos, neoplasias malignas óseas primarias, mieloma o histiocitosis X.1,4

El tratamiento suele ser paliativo y se basa en el uso de la radioterapia, quimioterapia y hormonoterapia, 4,12-17 reservando la cirugía para casos aislados. ${ }^{18}$

El pronóstico, en general, es malo, con supervivencias tras el diagnóstico menores de un año. 4,5,17

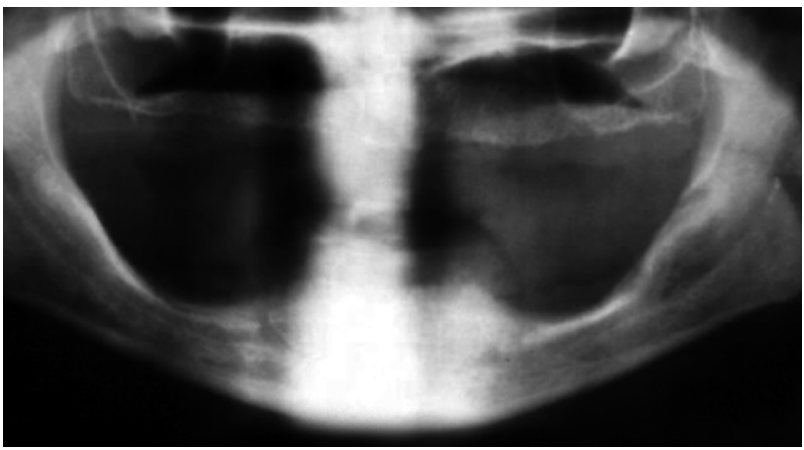

Figura 1. Ortopantomografía mostrando la lesión a nivel de la rama ascendente mandibular izquierda.

Figure 1. Orthopantomography showing lesion in left ascending ramus of mandible.

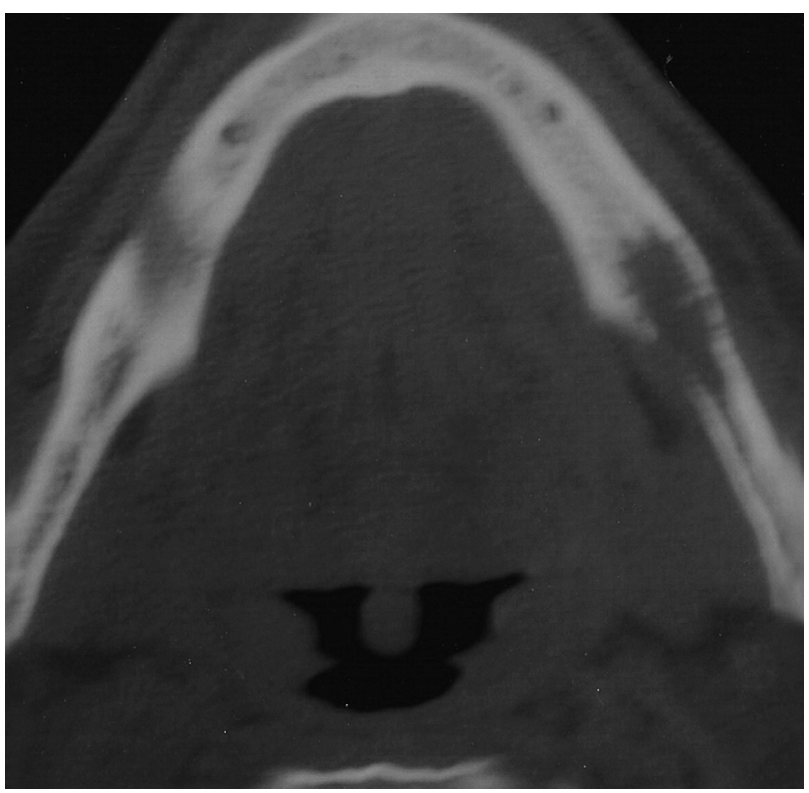

Figura 2. TC mandibular mostrando la lesión osteolítica en cuerpo mandibular.

Figure 2. CT scan of mandible showing osteolytic lesion of mandibular body.

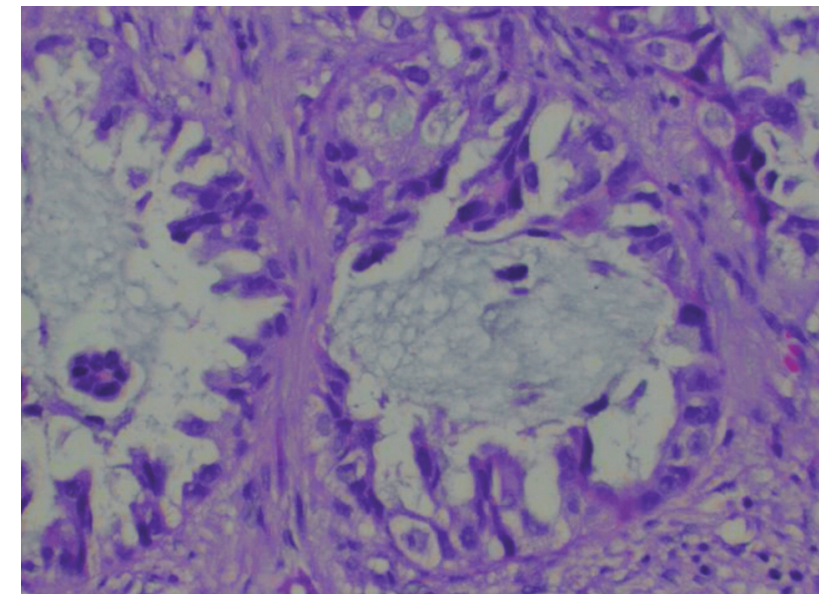

Figura 3. Imagen histopatológica de la biopsia (HE x 400). Figure 3. Histopathologic view of biopsy (HEx 400).

\section{Introduction}

Malignant tumors in the oral cavity and mandible represent approximately 5\% of all malignant neoplasms of the body, and only between 1 and $4 \%$ are considered to be metastatic. ${ }^{1,2}$ They are most commonly located in the mandible (80\%), fundamentally in the molar region. ${ }^{3,4}$ The most common origin is from primary tumors that arise in the breast, lung, kidneys, thyroid gland, intestines and prostrate; and to a lesser extent in the stomach, testes and bladder. ${ }^{5-7}$

They tend to affect the elderly (4th to $7^{\text {th }}$ decades of life) and there are no gender differences, 1,6,7 although there are authors that claim that there is a greater incidence in females compared with males. 4,5

The most common clinical presentation is of a painful mass that grows relatively rapidly in the mandibular molar region. 1,4,5,7 Other less common manifestations include paresthesia of the lower lip, movement or loss of teeth, as well as the presence of intraoral bleeding. ${ }^{8-}$ 10 Bilateral or multicentric involvement has been described in the mandible, although this is exceptional. ${ }^{11}$ Radiological diagnosis is complicated as there is no pathognomonic appearance and sometimes there will be inexistent radiologic findings. When there are findings, these show a radiolucid image with badly defined margins, although at times, as in the case of breast or prostate metastases, the image can be radiopaque. 9,10 


\section{Caso clínico}

Varón de raza caucásica de 59 años de edad que es remitido a nuestro Servicio refiriendo dolor lancinante en el cuerpo mandibular izquierdo así como hipoestesia labio - mentoniana de ese mismo lado desde hacía un mes. La exploración intraoral fue normal. Se realizó un estudio radiográfico mediante ortopantomografía y TC que reveló la presencia de una lesión osteolítica bien delimitada de unos $2,5 \mathrm{~cm}$ de diámetro localizada a nivel de la rama ascendente mandibular izquierda (Figs. 1 y 2 ). Se llevó a cabo una biopsia de la lesión. El estudio histológico demostró una imagen compatible con lesión metastásica de adenocarcinoma, probablemente de tipo mucosecretor (Fig. 3). Se realizó entonces una gammagrafía ósea que mostró zonas de hipercaptación en la rama ascendente mandibular izquierda, cuerpo vertebral izquierdo a nivel de T12, $8^{\text {a }}$ costilla derecha y en unión costocondral de $6^{\text {a }}$ costilla derecha (Fig. 4). La TC toraco - abdominal evidenció una gran masa afectando al cuerpo y antro gástrico, con adenopatías regionales y un nódulo en el lóbulo superior pulmonar izquierdo (Fig. 5). Se le administró un tratamiento combinado con radio y quimioterapia. El paciente falleció 2 meses después. La autopsia confirmó el origen gástrico de la metástasis.

\section{Discusión}

Las metástasis mandibulares son infrecuentes. Clausen y Poulsen, ${ }^{3}$ definieron unos criterios para considerar un tumor mandibular como metastásico: 1) La lesión representa un carcinoma metastásico en el hueso, excluyendo la extensión desde tejidos blandos adyacentes; 2 ) tiene que confirmarse histológicamente; 3 ) debe identificarse la localización primaria del tumor; y 4) cuando la lesión primaria esté anatómicamente cerca de la metástasis, debe descartarse que sea una infiltración por contigüidad identificando un amplio margen libre de tumor alrededor del mismo. Estos cuatro criterios no han sido correctamente aplicados en algunos casos de metástasis mandibulares previamente descritos en la literatura, ${ }^{1,4}$ por lo que su frecuencia podría ser incluso menor. El caso descrito en este artículo cumple perfectamente los cuatro criterios antes mencionados (Tabla 1).

Meyer y Shklar en 1965 estudiaron 2.400 casos de carcinomas; 25 de ellos fueron metástasis y solo en 1 el tumor primario asenta-
The differential diagnosis includes various entities with a radiologic appearance that is similar to osteomyelitis, abscesses and bone cysts, primary malignant bone neoplasms, myelomas or histiocytosis X.1,4

Treatment tends to be palliative and it is based on the use of radiotherapy, chemotherapy and hormonotherapy, 4,12-17 while surgery is to be kept for isolated cases. 18

Generally it has a bad prognosis with survival after diagnosis of less than a year. $4,5,17$

\section{Case report}

A Caucasian male, 59 years old was sent to our department complaining of a leftsided stabbing pain in the mandibular body as well as hypoesthesia of the lip and chin on the same side, which had been evolving for over a month. The intraoral examination was normal. A radiographic study was carried out that included an orthopantomography and a CAT scan that revealed the presence of an osteolytic lesion that was well-defined, with a diameter of less than $2.5 \mathrm{~cm}$, and which was located in the left ascending ramus of the mandible (Figs. 1 and 2). A biopsy of the lesion was carried out. The histological analysis revealed an image that was compatible with a metastatic adenocarcinoma lesion, probably of the mucosecretory type (Fig. 3). A bone gammagraphy was carried out that revealed hyperuptake in the left ascending ramus of the mandible, left vertebral body by $T 12,8$ th rib on right side and costochondral joint of 6 th rib on right side (Fig. 4). The thorasic-abdominal CAT scan revealed a large mass that affected the gastric body and antrum, with regional adenopathy, and a nodule in the upper lobe of the left lung (Fig. 5). Combined radio and chemotherapy was administered. The patient died two months later. The autopsy confirmed the gastric origin of the metastases.

Discussion 
ba en estómago. ${ }^{4}$ Resultados similares fueron reportados por Zachariades y cols. ${ }^{6}$ que revisaron 204 publicaciones hasta 1989 sobre metástasis en región maxilofacial, encontrando 422 implantes metastásicos, de ellos, sólo 5 tenían un origen gástrico. Wu, en una serie de 2409 tumores malignos de cavidad oral y mandíbula, encontró que sólo 25 de ellos eran metastásicos, y que sólo en 2 de ellos el tumor primario asentaba en el estómago. ${ }^{8}$ La localización más frecuente de las metástasis en el área maxilofacial es intraósea en la mayor parte de los estudios, 4,6 afectando a la mandíbula en un $61 \%$ de los casos, al maxilar superior en un $24 \%$. Más de un $20 \%$ de los casos de metás-

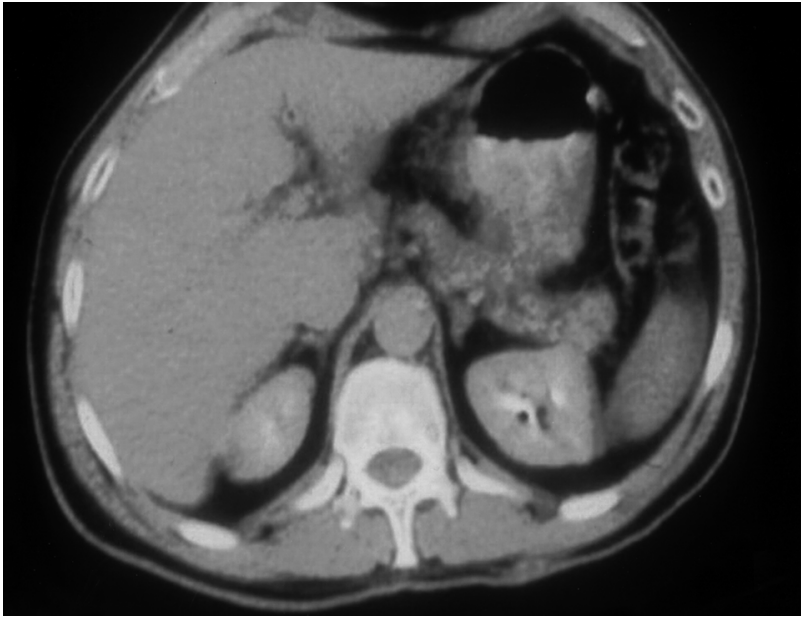

Figura 5. TC toraco-abdominal mostrando la lesión gástrica Figure 5. CT scan of thorax and abdomen showing gastric lesion.

tasis localizadas en la lengua fueron detectadas postmortem durante la autopsia, lo que puede hacer pensar que la lengua está afectada con más frecuencia de lo que se creía anteriormente. Por el contrario, Nishimura y cols., en su revisión de la literatura japonesa, encontraron una mayor frecuencia de metástasis gingivales que óseas. 5,6

Las metástasis óseas de carcinoma gástrico son un hallazgo clínico infrecuente. Sin embargo, esto probablemente ocurra con mayor frecuencia de los que demuestran los estudios radiológicos debido a la no realización de un estudio óseo completo durante la autopsia. Se han descrito entre un 5 y un $11 \%$ de metástasis óseas de adenocarcinoma gástrico, siendo el lugar de asiento más frecuente las vértebras. ${ }^{9}$ La afectación de los huesos faciales es muy rara, aunque Hashimoto y cols. ${ }^{10}$ en su estudio sobre autopsias en pacientes fallecidos a causa de carcinomas gástricos encontraron metástasis mandibulares en 3 casos (25\%).

Tabla 1. Mayores series descritas

$\begin{array}{lcc}\text { Series } & \begin{array}{c}\text { Metástasis } \\ \text { mandibulares }\end{array} & \begin{array}{c}\text { Tumor primario } \\ \text { gástrico }\end{array} \\ \text { Clausen y Poulsen, 1963 } & 97 & 5 \\ \text { McDaniel y cols, 1971 } & 29 & 0 \\ \text { Meyer y Shklar, 1965 } & 25 & 1 \\ \text { Wu, 1990 } & 25 & 2 \\ \text { Zachariades N, 1989 } & 422 & 5 \\ \text { Nishimura, 1982 } & 41 & 5 \\ \text { Castigliano y Rominger, 1987 } & 176 & 3 \\ \text { Cash y cols, 1961 } & 20 & 0 \\ \text { Stypulkowska y cols, 1979 } & 13 & 0 \\ \text { Fukuda y cols, 2002 } & 9 & 1 \\ \text { Aniceto y cols, 1990 } & 9 & 1\end{array}$

Table 1. Largest series described

Series

Clausen and Poulsen, 1963

McDaniel et al, 1971

Meyer and Shklar et al, 1965

Wu, 1990

Zachariades N, 1989

Nishimuraet alet al, 1982

Castigliano and Rominger, 1987

Cash et al, 1961

Stypulkowska et al, 1979

Fukuda et al, 2002

Aniceto et al, 1990

Diferentes hipótesis han sido descritas para intentar explicar el hecho de que la mayor parte de las metástasis ocurran en las regiones más posteriores de la mandíbula; así, Hashimoto y cols. ${ }^{10}$ y Carroll y cols. ${ }^{11}$ creen que las áreas hematopoyéticas en la medular mandibular podrían favorecer el depósito precoz de las células tumorales. Holland y cols. ${ }^{12}$ consideran que es debido al hecho de que las metástasis óseas ocurren con mayor frecuencia en la médula

$\begin{array}{cc}\begin{array}{c}\text { Mandibular } \\ \text { metastases }\end{array} & \begin{array}{c}\text { Primary gastric } \\ \text { tumor }\end{array} \\ 97 & 5 \\ 29 & 0 \\ 25 & 1 \\ 25 & 2 \\ 422 & 5 \\ 41 & 5 \\ 176 & 3 \\ 20 & 0 \\ 13 & 0 \\ 9 & 1 \\ 9 & 1\end{array}$

Mandibular metastases are very uncommon. Clausen and Poulsen 3 defined some criteria for judging a mandibular tumor as metastasic or not: 1) The lesion represents a metastasic carcinoma in the bone, and any extension from adjacent soft tissue should be excluded; 2) it should be histologically confirmed; 3) the primary location of the tumor should be identified; and 4) when the primary lesion is anatomically close to the metastasis, direct extension should be ruled out and a wide tumor-free margin around the tumor itself should be identified. These four criteria have not been correctly applied in some cases of mandibular metastasis previously described in the literature, ${ }^{1,4}$ and the incidence rate as a result could be even lower. The case described in this article meets these four criteria perfectly. In 1965 Meyer and Shklar studied 2400 cases of carcinoma. Twenty-five were metastases and only in one case was the primary tumor in the stomach. ${ }^{4}$ Similar results were reported by Zachariades and cols. 6 who reviewed 204 publications up until 1989 on metastases in the maxillofacial region, and they found 422 metastatic lesions. Of these, only five had a gastric origin. In a series of 2409 malignant tumors of the oral cavity and mandible, Wu found that only 25 were metastatic and that in only two cases had the primary tumor arisen in the stomach. ${ }^{8}$ In most of the studies that have been carried out the most common location of metastases in the maxillofacial area is 
ósea roja que en la amarilla. El tipo de médula ósea predominante en la mandíbula es la amarilla. La médula ósea roja no es detectable hasta en el $75 \%$ de los adultos, pero cuando existe, se suele localizar en las regiones posteriores a los incisivos. Esto, sin embargo, no explica por qué la mayor parte de las metástasis ocurren en la mandíbula y no en el maxilar superior, en donde el hueso medular es más abundante. Para explicar por qué algunas metástasis mandibulares aparecen sin haberse afectado antes el pulmón, se describe el plexo de Batson, que suministra sangre arterial a un área que se extiende desde la base del cráneo hasta el sacro y que se anastomosa en el polígono de Willis con la carótida interna evitando así el filtrado pulmonar.6,13

Tanto los hombres como las mujeres están afectados con la misma frecuencia, ${ }^{6}$ o con un ligero predominio por las mujeres (52$62 \%) .{ }^{5}$ La edad de presentación oscila entre la $4^{\text {a }}$ y la $7^{\mathrm{a}}$ décadas de la vida. $3,4,14$ Aunque generalmente se describen metástasis mandibulares únicas, a veces, aunque de forma excepcional, pueden ocurrir de forma bilateral. ${ }^{15}$

Los principales signos clínicos son la presencia de una masa y el dolor. Otros autores,, 16 como en nuestro caso, encuentran que las alteraciones de la sensibilidad en el labio inferior son el signo más frecuente. En aproximadamente el $20-30 \%$ de los casos la metástasis se diagnostica antes que el tumor primario, $4,17,18$ y la mayor parte de estos pacientes fallece antes del primer año tras el diagnóstico. Parece existir una diferencia en el tiempo de supervivencia de los pacientes en los que la metástasis se diagnostica antes que el tumor primario con respecto a aquellos en los que se diagnostica antes el primario que la metástasis, con una mayor tasa de supervivencia en estos últimos. ${ }^{17}$

El tratamiento paliativo es de elección en este tipo de pacientes e incluye la radioterapia, quimioterapia y hormonoterapia, ${ }^{17}$ reservando la cirugía para casos seleccionados, fundamentalmente cuando no existan otras metástasis o por motivos puramente estéticos. 5,18

\section{Bibliografía}

1. McDaniel RK, Luna MA, Stimson PG. Metastatic tumors in the jaws. Oral Surg Oral Med Oral Pathol 1971;31:380-6.

2. Batsakis JG. Tumors of head and neck: clinical and pathologic considerations. 2nd ed. Baltimore: William \& Wilkins 1979;240.

3. Clausen F, Poulsen H. Metastatic carcinoma to the jaws. Acta Pathol Microbiol Scand 1963;57:361-74.

4. Meyer I, Shklar G. Malignant tumors metastatic to mouth and jaws. Oral Surg Oral Med Oral Pathol 1965;20:350-62.

5. Nishimura Y, Yakata H, Kawasaki T, y cols. Metastatic tumors of the mouth and jaws: A review of the Japanes literature. J Maxillofac Surg 1982;4:253-8.

6. Zachariades N. Neoplasms metastatic to the mouth, jaws and surrounding tissues. J Craniomaxillofac Surg 1989;17:283-90.

7. Stypulkowska J, Barktkowski S, Pana M, y cols. Metastatic tumors to the jaws and oral cavity. J Oral Surg 1979;37:805-8.

8. Wu YT. Metastatic carcinoma to the oral tissues and jaws: a study of 25 cases. Zhonghua Kou Qiang Yi Xue Za Zhi 1990;25:258-61.

9. Catone GA, Henny FA. Metastatic gastric adenocarcinoma of the mandible: report of a case. J Oral Surg 1969;27:36-40. intraosseous, 4,6 and the mandible is affected in 61\% of cases, and the maxilla in $24 \%$. More than $20 \%$ of the metastases cases located in the tongue were detected postmortem during the autopsy, which would suggest that the tongue is affected more than has previously been thought. On the other hand Nishimura and cols., in a revision of the Japanese literature found greater frequency of gingival metastases than bone. ${ }^{5,6}$

Bone metastases of gastric carcinoma are clinically uncommon findings. However, this probably occurs with greater frequency than has been demonstrated in radiological studies due to complete bone studies not being carried out during autopsies. Between 5 and $11 \%$ of bone metastases of gastric adenocarcinoma has been described, arising most commonly in the vertebrae. ${ }^{9}$ It is very rare for the facial bones to be affected although Hashimoto and cols. ${ }^{10}$ in a study on autopsies of deceased patients due to gastric carcinomas, found mandibular metastases in 3 cases (25\%).

Different hypotheses have been put forwards in an attempt to explain the fact that most of the metastases occur towards the back of the mandible. Thus Hashimoto and cols. ${ }^{10}$ and Carroll and cols. ${ }^{11}$ believe that the hematopoietic areas in mandibular bone marrow could favor the early deposit of tumor cells. Holland and cols..$^{12}$ are of the opinion that this is due to the fact that bone metastases occurs with greater frequency in red bone marrow than in yellow. The type of predominant bone marrow in the mandible is yellow. Red bone marrow cannot be detected in up to $75 \%$ of adults, but when it exists it tends to be located in the region behind the incisors. However, this does not explain why most metastases occur in the mandible and not in the maxilla where there is greater medullar bone. In order to explain why some mandibular metastases appear without first affecting the lungs, a description has been made of Batson's plexus that supplies arterial blood to an area that extends from the skull base to the sacrum, and that in Willis' polygon anastomosis occurs with the internal carotid artery, and lung filtration is in this way avoided. 6,13

Men and women are affected at the same rate, 6 although there is a slight female predominance (52-62\%). ${ }^{5}$ The age at presentation varies between the $4^{\text {th }}$ and the $7^{\text {th }}$ decades in life.3,4,14 Although in general mandibular metastasis on its own is described, it can sometimes be bilateral although this is exceptional. ${ }^{15}$

The principal clinical signs are the presence of a mass and pain. Other authors ${ }^{8,16}$ found sensory disturbance of the lower lip, as occurred in this case of ours. In approximately $20-30 \%$ of cases metastasis was diagnosed before the primary tumor, $4,17,18$ and most of these patients died within a year of being diagnosed. There appears to be a difference in the survival times of patients who are diagnosed with metastases before the primary tumor is diagnosed, compared with those whose primary tumor is diagnosed before the metastasis, as the latter have a greater survival rate. ${ }^{17}$ 
10. Hashimoto N, Kurihara K, Yamassaki H, y cols. Pathological characteristics of metastatic carcinoma in the human mandible. J Oral Pathol 1987;16:362-7.

11. Carroll MK, Krolls SO, Mosca NG. Metastatic carcinoma to the mandible. Oral Surg Oral Med Oral Pathol 1993;76:368-74.

12. Holland DJ. Metastatic carcinoma to the mandible. Oral Surg Oral Med Oral Pathol 1953;6:567-72.

13. Wolujewicz MA. Condilar metastasis from a carcinoma of the prostate gland. $\mathrm{Br}$ J Oral Surg 1980;18:175-82.

14. Cash CD, Royer RQ, Dahlin DC. Metastatic tumours of the jaws. Oral Surg 1961; 14:897-901.

15. McMillan MD, Edwards JL. Bilateral mandibular metastases. Oral Surg Oral Med Oral Pathol 1975;39:959-66.

16. Rohrer MD, Colyer J. Mental nerve paresthesia: Symptom for a widespread skeletal metastatic adenocarcinoma. J Oral Surg 1981;39:442-5.

17. Fukuda MF, Miyata M, Okabe K, Sakashita H. A case series of 9 tumors metastatic to the oral and maxillofacial region. J Oral Maxillofac Surg 2002;60:942-94.

18. Aniceto GS, Penín AG, de la Mata R, y cols. Tumors metastatic to the mandible: Análisis of nine cases and review to the literature. J Oral Maxillofac Surg 1990; 48:246-51.
Palliative treatment should be chosen for this type of patient and this includes radiotherapy, chemotherapy and hormonotherapy, ${ }^{17}$ surgery is reserved for selected cases, fundamentally when there is no other metastasis or for purely aesthetic reasons. 5, 18 